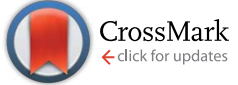

Cite this: RSC Adv., 2015, 5, 86867

Received 4th August 2015

Accepted 8th October 2015

DOI: 10.1039/c5ra15601g

www.rsc.org/advances

\title{
Removal of a reactive dye and hexavalent chromium by a reusable bacteria attached electrospun nanofibrous web $\uparrow$
}

\author{
Nalan Oya San Keskin, ${ }^{\star a b c}$ Aslı Celebioglu, ${ }^{\text {cd }}$ Omer Faruk Sarioglu, ${ }^{\text {cd }}$

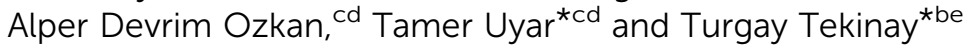

A contaminant resistant Lysinibacillus sp. NOSK was isolated from a soil sample and its Reactive Black 5 (RB5) and $\mathrm{Cr}(\mathrm{VI})$ removal efficiencies were investigated as a function of changes in the initial $\mathrm{pH}$ values, temperature, static/shaking conditions, reactive dye and $\mathrm{Cr}(\mathrm{VI})$ concentrations. In this study, an electrospun polysulfone nanofibrous web (PSU-NFW) was found to be effective in attachment of bacterial cells. Bacteria attached PSU-NFWs (bacteria/PSU-NFW) have shown highly efficient removal of RB5, as $99.7 \pm 0.9 \%$ and $35.8 \pm 0.4 \%$ for the pristine PSU-NFW. Moreover, the highest Cr(vI) removal efficiencies measured were $98.2 \pm 0.6 \%$ for bacteria attached PSU-NFW and $32.6 \pm 0.6 \%$ for the pristine PSU-NFW. Simultaneous removal of RB5 and Cr(vI) were also investigated. Reusability test results indicate that, bacteria/PSU-NFW can be reused for at least 7 cycles with $28.1 \pm 0.6 \%$ and $66.7 \pm 0.8 \%$ removal efficiencies for RB5 and Cr(vi), respectively.

\section{Introduction}

The progression in civilization and industrial activities has caused a number of environmental problems. For decades, large quantities of pollutants have been discharged into nature irresponsibly. For this reason, water pollution control is presently one of the major scientific research areas. ${ }^{\mathbf{1 , 2}}$ Pollutants found in textile effluents include synthetic dyes and heavy metals such as copper, chromium, and cobalt (found in metal complex dyes) which are used for dye fixation in wool dyeing, as reducing agents and dye bath additives in sulphate salts. ${ }^{3}$ Dyes are difficult to be decolorized due to their complex structure, synthetic origin and recalcitrant nature. In this case, it makes obligatory to remove them from industrial effluents before being disposed into aquatic environments. Especially, watersoluble reactive dyes are the most problematic, as they tend to pass unaffected through conventional treatment systems. ${ }^{4}$

${ }^{a}$ Polatl Science and Literature Faculty, Biology Department, Gazi University, Ankara 06900, Turkey. E-mail: oyasan@gazi.edu.tr; Fax: +90-312-484-6271; Tel: +90-312484-6270

${ }^{b}$ Life Sciences Application and Research Center, Gazi University, Ankara 06830, Turkey ${ }^{c}$ UNAM-National Nanotechnology Research Center, Bilkent University, Ankara 06800, Turkey. E-mail: tamer@unam.bilkent.edu.tr; Fax: +90-312-266-4365; Tel: +90-312290-3571

${ }^{d}$ Institute of Materials Science and Nanotechnology, Bilkent University, 06800 Ankara, Turkey

${ }^{e}$ Faculty of Medicine, Department of Medical Biology and Genetics, Gazi University, Ankara 06560, Turkey.E-mail: ttekinay@gazi.edu.tr

$\dagger$ Electronic supplementary information (ESI) available. See DOI: 10.1039/c5ra15601g
Dyes used in industrial sites include several structural forms such as acidic, reactive, basic, disperse, azo, diazo, anthraquinone based and metal-complex dyes. ${ }^{5}$ Production and usage of synthetic dyes and pigments have exceeded 700000 tons worldwide. ${ }^{6}$ During the past two decades, several decolorization techniques have been reported, few of them have been accepted by industries. Thus, there is a need to find alternative costeffective and efficient treatments to remove dyes and colorants from effluents.

Due to non-degradable property, metals are particularly problematic compared to most organic pollutants. Metals can accumulate in living tissues, thus their concentration increases throughout the food chain. By this way, higher doses can detrimentally affect the health of most living organisms. ${ }^{7}$ Chromium is one of the most widely used metals in industries, such as petroleum refining, wood preservation, pulp production, leather tanning, dye manufacturing and electroplating. ${ }^{8}$ Chromium primarily exists in the forms of $\mathrm{Cr}(\mathrm{VI})$ and $\mathrm{Cr}$ (III) in the natural environment. While $\mathrm{Cr}(\mathrm{vI})$ oxyanions are very mobile in the nature, $\mathrm{Cr}(\mathrm{III})$ cations are not. Especially, hexavalent chromium brings environmental concern due to its toxicity and mobility. It penetrates quickly through most environments such as soil and aquatic environments. It is carcinogenic and mutagenic due to its strong oxidizing agent property. Like many metal cations, Cr(III) forms insoluble precipitates depending on parameters such as $\mathrm{pH}$. Thus, at the end of the removal process, $\mathrm{Cr}(\mathrm{vI})$ is reduced to $\mathrm{Cr}(\mathrm{III})$, so reduces its toxicity and mobility. There are three stage of microbial $\mathrm{Cr}(\mathrm{vI})$ removal from solutions: (a) the chromium binding to the cell surface, (b) chromium translocation into the cell, and (c) $\mathrm{Cr}$ (VI) reduction to $\mathrm{Cr}(\mathrm{III}) .{ }^{9} \mathrm{At}$ 
present, conventional technologies such as ion exchange, ${ }^{\mathbf{1 0}}$ chemical precipitation ${ }^{\mathbf{1 1}}$ and reverse osmosis ${ }^{\mathbf{1 2}}$ are used to remove dyes and $\mathrm{Cr}(\mathrm{vI})$ from the contaminated environments. But it is not cost effective and also these methods may cause secondary environmental pollution.

Bioremoval techniques based on microorganisms have been developed and considered to be efficient, economic and environmentally friendly for treating contaminants such as dyes and toxic heavy metals. ${ }^{\mathbf{1 3 , 1 4}}$ Bacteria decolorize dye by adsorption or degradation. Dye adsorption can be clearly judged by inspecting the cell mass as those adsorbing dyes will be deeply colored, whereas those causing degradation will remain colorless. ${ }^{15}$

Electrospinning is a novel technology for the fabrication of nanofibers with diameters lower than $100 \mathrm{~nm}$. The process gained attention due to its simplicity, versatility and cost effectiveness. ${ }^{16,17}$ Electrospun nanofibers and webs display a variety of unique properties such as nanofibers possess an extremely high surface-to-volume ratio which can provide a large specific surface area for highly efficient immobilization and a nanoscale pore size. ${ }^{18-22}$

The integration of electrospun nanofibrous webs with microorganisms can enhance the potential of these NFW's for the filtration and purification purposes and have a great potential for the environmental practices. There are few studies in the literature about incorporation of microorganisms in electrospun nanofibers. ${ }^{23-26}$ For instance, Greque de Morais et $a l .{ }^{24}$ produced thin bead-free nanofibers from Spirulina sp. biomass as extracellular matrices for stem cell culture and future treatment of spinal chord injury. One of the related study was performed by our group in which Acinetobacter calcoaceticus STB1 cells were immobilized on electrospun cellulose acetate nanofibrous webs (CA-NFW) in order to achieve enhanced ammonium removal in aqueous environments. ${ }^{26}$ Moreover, Eroglu et al. ${ }^{23}$ have shown in their study that, algal cells were effectively immobilized on electrospun chitosan nanofiber mats to generate a hybrid system for nitrate removal. In our recent study, decolorization of methylene blue (MB) dye in aqueous medium was achieved by using three types of bacteria (Aeromonas eucrenophila, Clavibacter michiganensis and Pseudomonas aeruginosa) that were immobilized on the CA-NFW within 24 hours and the $\mathrm{MB}$ dye removal efficiency was $\sim 95 \%$. $^{27}$ Moreover, in our very recent study, we have developed microalgae immobilized by polysulfone nanofibrous web (microalgae/ PSUNFW) for the removal of reactive dyes (RB5 and Reactive Blue 221 (RB221)). The decolorization efficiency rate for RB5 was calculated as $72.97 \pm 0.3 \%$ for microalgae/PSU-NFW, whereas it was $12.36 \pm 0.3 \%$ for the pristine PSU-NFW. ${ }^{25}$

The aim of the present study is to evaluate and present an efficient methodology for treatment of industrial textile wastewater containing dyes and heavy metals by using a novel nanobiocomposite which was developed by immobilization of a newly isolated contaminant resistant bacterial strain on PSU nanofibrous web for the adsorptive and biological removal of Reactive Black 5 (RB5) and $\mathrm{Cr}(\mathrm{vI}$ ), individually as well as simultaneously. In the light of literatures, there are no reports in the context when such bacteria were attached to electrospun
NFW for the single and binary removal of dye and heavy metals. To maximize the removal efficiency of dye and heavy metal through bacteria/PSU-NFW, we have studied decolorization time, initial $\mathrm{pH}$, static and shaking conditions, temperature and different initial dye and $\mathrm{Cr}(\mathrm{vI})$ concentrations. At the end, the reusability of bacteria/PSU-NFW was tested as well.

\section{Experimental}

\section{Contaminants: reactive dye and heavy metal}

The textile dye, RB5 was obtained from SETAŞ Chemistry Factory (Tekirdağ, Turkey). Cr(vi) solutions were prepared by diluting $\mathrm{K}_{2} \mathrm{Cr}_{2} \mathrm{O}_{7}$ (Riedel-de Haen) stock solution using distilled water. Appropriate volumes of the stock RB5 and $\mathrm{Cr}(\mathrm{vI})$ solutions were added to nutrient broth (NB) media containing flasks. The concentrations of dye in each aqueous solutions were measured on an UV-Vis spectrophotometer (Shimadzu UV-1800) by measuring their absorbance at $597 \mathrm{~nm}$. Hexavalent chromium was quantified by measuring the absorbance of the purple complex of $\mathrm{Cr}(\mathrm{vI})$ with 1,5-diphenylcarbazide in acidic solution at $540 \mathrm{~nm}$. All the chemicals were of high purity available and were of analytical grade.

\section{Analytical methods}

Contaminants were added into the $24 \mathrm{~h}$ grown bacterial cultures. Aliquots of samples $(4 \mathrm{~mL})$ were withdrawn at regular time intervals, centrifuged at $10000 \mathrm{rpm}$ for $10 \mathrm{~min}$, and the supernatants were utilized for determination of the contaminant concentrations. Removal efficiency of RB5 and Cr(vI) were determined by absorbance reduction for both single and binary effects experiments.

The percentages of bioremoval were calculated from the difference between initial and final values using the following formula eqn (1)

$$
\text { Removal\% } \%=\frac{C_{0}-C_{\mathrm{eq}}}{C_{0}} \times 100
$$

where $C_{0}$ and $C_{\text {eq }}$ are the initial and equilibrium concentrations of pollutants $\left(\mathrm{mg} \mathrm{L}^{-1}\right)$, respectively.

Each experiment consisted of triplicate batches. Each result is an average of three parallel replicates. \pm indicates standard deviation among the replicates.

\section{Electrospinning of polysulfone nanofibrous web (PSU-NFW)}

The electrospinning of porous CA-NFW was performed as detailed in our previous studies. ${ }^{25}$ Solvents of the DMAc/acetone binary system were purchased and used without any purification ( $N, N$-dimethylacetamide, DMAc, $\geq 99 \%$, Sigma Aldrich; acetone, $\geq 99 \%$ (GC), Sigma Aldrich; polysulfone, $M_{\mathrm{w}} \sim 60000$, Scientific Polymer Products, Inc.). The clear electrospinning solution was prepared by dissolving PSU in a DMAc/acetone (9/1 $(\mathrm{v} / \mathrm{v}))$ binary solvent mixture at a $32 \%(\mathrm{w} / \mathrm{v})$ polymer concentration. Then, this solution was filled in a $3 \mathrm{~mL}$ syringe fitted with a metallic needle of a $0.4 \mathrm{~mm}$ inner diameter. The syringe was located horizontally on the syringe pump (model KDS-101-CE, KdScientific, USA). The electrode of the high-voltage power 
supply (Spellman, SL30, USA) was clamped to the metal needle tip, and the plate aluminum collector was grounded. Electrospinning parameters were arranged as follows: feed rate of solutions $=0.5 \mathrm{~mL} \mathrm{~h}^{-1}$, applied voltage $=10 \mathrm{kV}$, tip-to-collector distance $=12 \mathrm{~cm}$. Electrospun nanofibrous web were deposited on a grounded stationary metal collector covered with aluminum foil. The electrospinning apparatus was enclosed in a Plexiglas box and electrospinning was carried out at $25{ }^{\circ} \mathrm{C}$ at $18 \%$ relative humidity. Collected nanofibers/nanowebs were dried in vacuum oven at $50{ }^{\circ} \mathrm{C}$ overnight to remove the solvent residuals.

\section{Isolation and identification of bacterium}

The soil sample was collected from the Ankara River at six inches depth from surface. A $10 \mathrm{~g}$ soil sample was agitated in $50 \mathrm{~mL}$ of saline solution $(0.8 \% \mathrm{NaCl})$ and incubated on an orbital shaker at $100 \mathrm{rpm}$ for $30 \mathrm{~min}$. Then $0.1 \mathrm{~mL}$ of suspension was plated on nutrient agar (NA) supplemented with 5.0\% methanol and then incubated at $37 \pm 1{ }^{\circ} \mathrm{C}$ for $48 \mathrm{~h}$. Methanol tolerant strains representing different colony morphologies were purified on the same agar medium, and stored at $-20{ }^{\circ} \mathrm{C}$.

Identification of the isolate was carried out using $16 \mathrm{~S}$ rDNA sequencing. 16S rDNA was amplified with primers forward (5 $\rightarrow$ $\left.3^{\prime}\right): 5^{\prime}$ AGAGTTTGATCCTGGCTCAG $3^{\prime}$ and reverse $\left(5^{\prime} \rightarrow 3^{\prime}\right): 5^{\prime}$ AAGGAGGTGATCCAGCCGCA $3^{\prime}$. Partial 16S rDNA gene sequencing was done at ABI 3130xl analyzer based on Sanger's dideoxy termination method at REFGEN, Ankara, Turkey. For phylogenetic analysis, reference strains were chosen from NCBI's GenBank and a phylogenetic tree was constructed with a neighbor-joining method. ${ }^{28}$

\section{Optimization of time for bacterial attachment to polysulfone nanofibrous web (PSU-NFW)}

Nutrient Broth (NB) medium (peptone from meat $5.0 \mathrm{~g}$, meat extract $3.0 \mathrm{~g}$ and sodium chloride $6.0 \mathrm{~g}$ in $1 \mathrm{~L}, \mathrm{pH} 7.0)(\mathrm{pH} 7.0)$ for using in bacterial immobilization experiments was sterilized and inoculated with $1 \mathrm{~mL}\left(\sim 10^{7} \mathrm{CFU} \mathrm{mL}^{-1}\right)$ of bacterial culture. $20 \mathrm{mg}$ of UV sterilized PSU-NFW were added to the inoculation flasks and incubated for different time periods; 24 h, 7 days and 15 days in a rotary shaker at $100 \mathrm{rpm}$ to find out the maximum bacterial attachment.

After completing the immobilization experiments for different time periods, the immobilized bacteria on bacteria/ PSU-NFW samples were quantified using a multi-step process of cell removal which contains sonication at a frequency of 40 $\mathrm{kHz}$ (Branson Ultrasonic Cleaner; Branson Ultrasonics, Danbury, CT) for $10 \mathrm{~min}$ and vortexing $30 \mathrm{~s}$. After detachment process the number of colony-forming units (CFU) per milliliter of suspension was determined by the plate counting technique. In addition, bacterial attachment was investigated by using scanning electron microscopy (SEM, Quanta 200 FEG, FEI).

\section{Characterization of polysulfone nanofibrous web}

The morphologies of pristine PSU-NFW, free bacteria and bacteria immobilized PSU-NFW were investigated by using SEM. Samples were washed twice with phosphate buffered saline (PBS) and fixed by overnight incubation in $2.5 \%$ glutaraldehyde solution at room temperature. $2.5 \%$ gluteraldehyde solution was used for bacterial fixation to inhibit cellular autolysis, to preserve cellular components and morphology, and to present cells with a distinct microscopical appearance. Then the samples were dehydrated by immersing in a series of ethanol-water solutions ranging from $20 \%$ to $100 \%$. Prior to SEM imaging, all samples were coated with a $5 \mathrm{~nm}$ layer of goldpalladium.

\section{Optimization of different parameters for removal of dye and heavy metal}

Optimization of different parameters for biological removal of dye and heavy metal by only bacterial isolate, was performed in NB medium containing both RB5 and $\mathrm{Cr}(\mathrm{vI})\left(30 \mathrm{mg} \mathrm{L}^{-1}\right)$. The effects of $\mathrm{pH}$ and temperature were monitored under static condition in the range of $5.0-10.0$ and $20{ }^{\circ} \mathrm{C}, 30{ }^{\circ} \mathrm{C}$ and $40{ }^{\circ} \mathrm{C}$, respectively. The effect of static and shaking culture on removal performance was studied at shaking (100 rpm and $200 \mathrm{rpm}$ ) and static conditions. Control flasks containing growth media, dye and heavy metals were used to observe any reactions of the media with the dye and heavy metals. Each of the measurements were performed in triplicate to follow the daily changes in the samples throughout the incubation period.

\section{Single and binary effects of initial dye and heavy metal concentration on bioaccumulation}

To determine the single effect of initial dye concentration, pristine PSU-NFW and bacteria/PSU-NFW were incubated in NB media containing $30 \mathrm{mg} \mathrm{L}^{-1}$ pollutants at $\mathrm{pH}$ 8.0.

Hexavalent chromium is extensively used in production of dyes as well as in dyeing processes. Therefore, to found binary effect, the efficiency of bacteria/PSU-NFW was tested for decolorization of dye $\left(15,50\right.$ and $\left.100 \mathrm{mg} \mathrm{L}^{-1}\right)$ in the presence of $\mathrm{Cr}(\mathrm{vI})$ (30 $\mathrm{mg} \mathrm{L}^{-1}$ ), and biological removal of $\mathrm{Cr}(\mathrm{vI})(15,50$ and 100 $\left.\mathrm{mg} \mathrm{L}^{-1}\right)$ in the absence or presence of RB5 $\left(30 \mathrm{mg} \mathrm{L}^{-1}\right)$.

\section{Viability by biomass concentration}

Optical densities were measured at $600 \mathrm{~nm}$ by using a spectrophotometer (Shimadzu UV-1800).

\section{Biosorption}

After 7 days of attachment process, bacteria/PSU-NFW was exposed to UV light to obtain dead cells for use in biosorption experiments. Removal of RB5 and $\mathrm{Cr}(\mathrm{vI})$ by dead bacteria/PSUNFW was carried out at identical conditions with the previous bioremoval experiments.

\section{Reusability experiments for bacteria immobilized PSU-NFW}

Simultaneous removal of RB5 and $\mathrm{Cr}(\mathrm{vI})$ were performed 7 times to assess the potential reusability of bacteria/PSU-NFW at an initial concentration of $30 \mathrm{mg} \mathrm{L}^{-1}$ for both contaminants. Before each cycle, bacteria/PSU-NFW pieces were washed three times with PBS. RB5 and $\mathrm{Cr}(\mathrm{vI})$ concentrations were measured at zero time and $24 \mathrm{~h}$. Each cycle was terminated after $24 \mathrm{~h}$ of total 
incubation and washing steps were repeated for bacteria/PSUNFW samples before the initiation of the next cycle. All tests were done in triplicates.

\section{Adsorption isotherms and kinetics studies}

Adsorption coefficients were estimated via five isotherm models (Freundlich, Langmuir, generalized Langmuir-Freundlich, linear, Toth) using the isotherm parameter fitting software IsoFit. ${ }^{29}$ The order of reactions were predicted by plotting zero, first, second and third order plots for removal of Cr(vI) or RB5, and comparing their $R^{2}$ values.

\section{Statistical analysis}

Student's $t$-test was applied for statistical analyses. Analyses were done by using the software Minitab Version 13.2 (Minitab Inc., USA) at a 0.05 level of probability.

\section{Results and discussion}

\section{Identification and characterization of the bacterial isolates}

The neighbor-joining phylogenetic tree based on the 16S rRNA phylogenetic analysis of the NOSK strain and SEM micrograph of the bacterium are investigated (ESI Fig. S1a†). NOSK strain shows closest identity (99\%) with the genus Lysinibacillus. Based on molecular characterization, the isolate was identified as Lysinibacillus and hereafter is referred as Lysinibacillus sp. NOSK. It can grow in the presence of $5.0 \%$ methanol, indicating its tolerance towards some contaminants. Accordingly, it was promising candidate for bioremediation of industrial effluents. The strain NOSK was deposited in GenBank with an accession number; KM241862 ${ }^{30}$ and the gene sequence is available under the accession number. SEM micrograph (ESI Fig. S1b †) revealed that Lysinibacillus sp. NOSK has a long rod-like shape and contains centrally located endospore.

\section{Bacterial attachment to polysulfone nanofibrous web (PSU- NFW)}

Fig. 1a shows the schematic representation of the electrospinning process for polysulfone nanofibrous web (PSU-NFW). Fig. 1b shows the photos of pristine PSU-NFW and bacteria cells attached to the surface of PSU-NFW after 7 days from the start of the growth experiments. As seen in Fig. 1c, SEM micrograph of bacteria attached on the surface is seen due to the increased concentration of bacteria cells on the PSU-NFW with respect to time.

\section{Effect of initial pH, temperature, static/shaking conditions and bacterial attachment time on $\mathrm{RB} 5$ dye and $\mathrm{Cr}(\mathrm{vI})$ removal}

It was reported that $\mathrm{pH}$ and temperature of medium significantly affects the microbial removal efficiency. ${ }^{31}$ The effect of $\mathrm{pH}$ value on dye and heavy metal removal at the end of $24 \mathrm{~h}$ of incubation was determined for the samples that had about $30 \mathrm{mg} \mathrm{L}^{-1}$ initial dye and heavy metal concentrations. The experiments were performed at $\mathrm{pH}$ 5.0-10.0. As shown in Fig. 2a, dye decolorization yields were $10.5-98.8 \%$ and $\operatorname{Cr}(\mathrm{vI})$
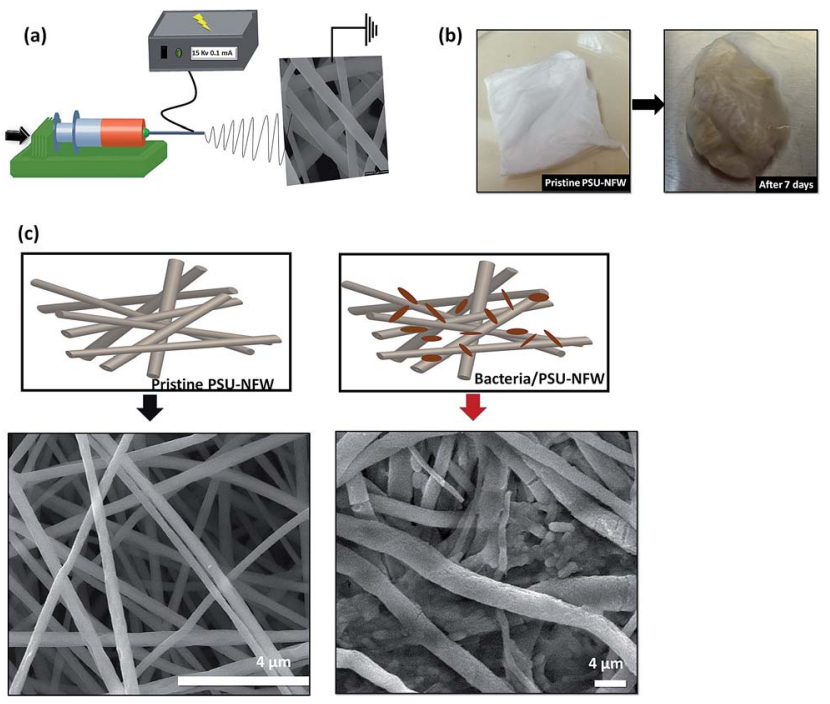

Fig. 1 (a) Schematic representation of the electrospinning process for PSU-NFW. (b) Photos of attachment of free bacteria cells on PSU-NFW for seven days process. (c) SEM micrographs of pristine PSU/NFW and bacteria/PSU-NFW

bioaccumulation yields were $72.5-97.4 \%$ after $24 \mathrm{~h}$ at all tested $\mathrm{pH}$ values. The lowest uptake yields were observed at $\mathrm{pH} 5.0$ and 10.0, which correspond to strongly acidic and basic conditions.

The RB5 and $\mathrm{Cr}(\mathrm{vr})$ removal yields of the bacterial cells were similarly high at $\mathrm{pH}$ 8.0. Moreover, the dye removal yield was significantly higher than the $\mathrm{Cr}(\mathrm{vI})$ removal yield. The $\mathrm{pH}$ of the dye containing wastewater discharged from textile factories usually ranged between 8.0 and 9.0. This result demonstrated that this strain can work at a wide range of $\mathrm{pH}(6.0-9.0)$, making it as a promising strain for practical bio-treatment of wastewater.

The simultaneous removal of RB5 and $\mathrm{Cr}(\mathrm{vI})$ at different temperatures is shown in Fig. 2b. Although the percentage of removal after $24 \mathrm{~h}$ was found to be comparatively low for both contaminants at $20^{\circ} \mathrm{C}$, it increased to a higher level at $30^{\circ} \mathrm{C}$ and reaches $98.8 \pm 0.34 \%$ for dye and $97.4 \pm 1.1 \%$ for $\operatorname{Cr}(\mathrm{vI})$. Nevertheless, the percentage of removal for both contaminants highly reduced when increasing the temperature to $40{ }^{\circ} \mathrm{C}$, implying the bacterium has a temperature preference for growth or its remediation activity in the order of $30{ }^{\circ} \mathrm{C}, 40{ }^{\circ} \mathrm{C}$ and $20^{\circ} \mathrm{C}$. In particular, decolorizing activity was substantially inhibited at 20 and $40{ }^{\circ} \mathrm{C}$, most likely because of deactivation of enzymes responsible for decolorization, or loss of cell viability. ${ }^{13}$ As a result, the removal yields of $\mathrm{Cr}(\mathrm{vI})$ exceeds $50 \%$ when the temperature is between $20{ }^{\circ} \mathrm{C}$ and $40{ }^{\circ} \mathrm{C}$, and the optimum temperature for treatment of both contaminants was found to be $30^{\circ} \mathrm{C}$.

As shown in Fig. 2c, Lysinibacillus sp. NOSK was able to grow in both static and shaking conditions. Due to an increase in biomass and oxygen transfer between cells and the medium, the decolorization ability of the isolate was significantly enhanced at 100 and $200 \mathrm{rpm}$, since the removal yields were found as $98.8 \pm 1.1 \%$ and $71.8 \pm 0.53 \%$ at these shaking speeds, respectively; while it was $40.7 \pm 1.2 \%$ under static conditions. 

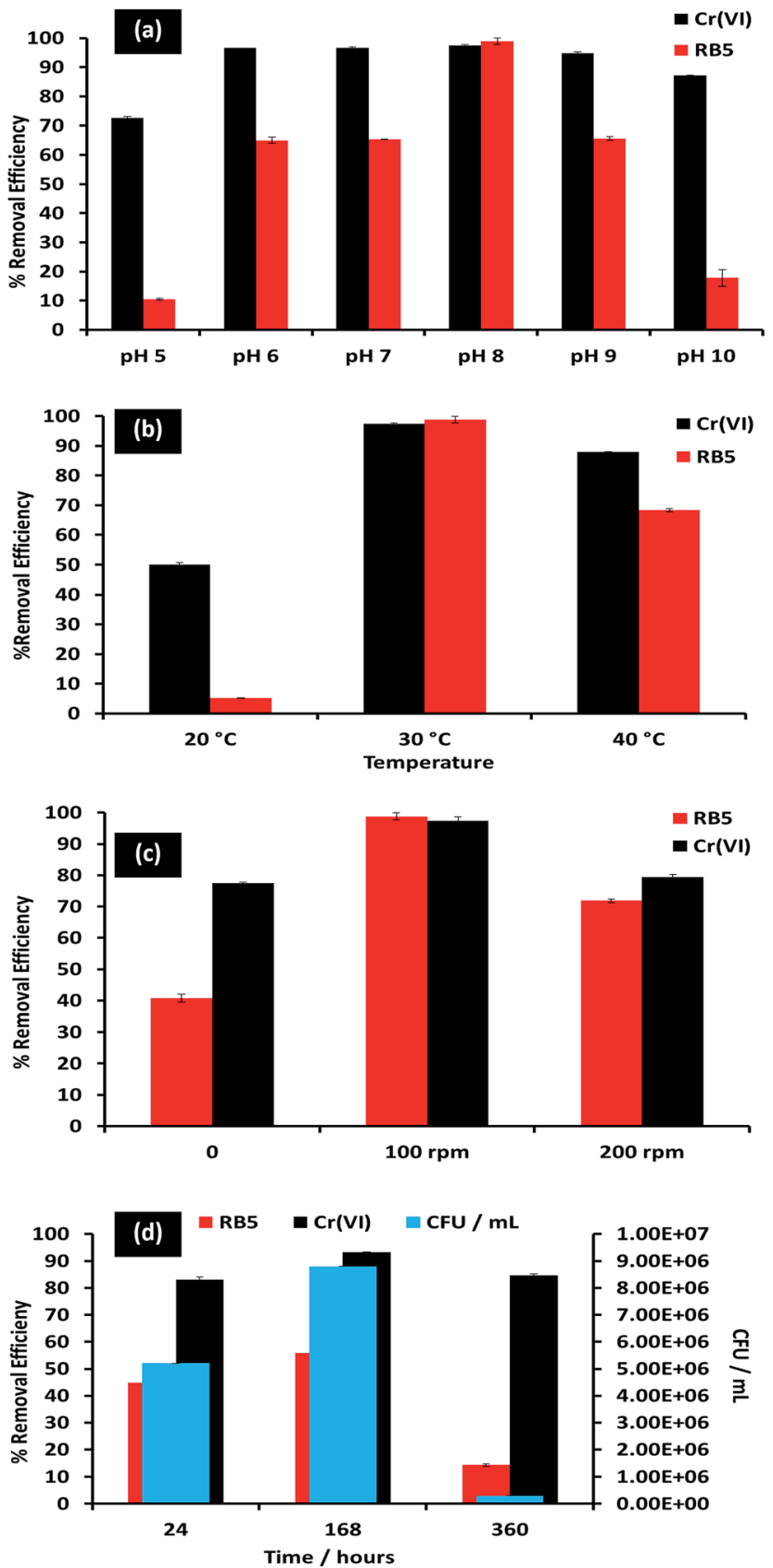

Fig. 2 Effects of (a) various $\mathrm{pH}$ values (b) different temperatures (c) static/shaking conditions and (d) effect of bacterial counts after incubating PSU-NFW's for different time periods ( $24 \mathrm{~h}, 7$ days and 15 days) on removal efficiency of RB5 and Cr(vı) by Lysinibacillus sp. NOSK after $24 \mathrm{~h}$ incubation. Error bars represent the means of three independent replicates.

The removal efficiencies for both contaminants decreased above $100 \mathrm{rpm}$, possibly due to a decrease in biomass production as bacterial cells might be stressed and could not grow well at very high shaking speeds, hence $100 \mathrm{rpm}$ was found as the optimum shaking speed for remediation of both contaminants.

Bacterial cell counting and bioremoval experiments were performed to find out the optimal time for maximum bacterial attachment, and the results are shown in Fig. 2d. Bacterial attachment process was initiated by adding bacterial inocula $\left(\sim 10^{7} \mathrm{CFU} \mathrm{mL}{ }^{-1}\right.$ cells) to NB media which containing pieces of PSU-NFW. After different periods of time for the attachment process, $\sim 5.2 \times 10^{6}$ cells per $\mathrm{mL}$ were counted for $24 \mathrm{~h}$ incubation with the maximum removal yields of $44.7 \pm 2.6 \%$ for RB5 and $83.05 \pm 0.9 \%$ for $\mathrm{Cr}(\mathrm{vI}), \sim 8.8 \times 10^{6}$ cells per $\mathrm{mL}$ were counted for 7 days of incubation with the maximum removal yields of $55.9 \pm 0.4 \%$ for RB5 and $93.2 \pm 0.1 \%$ for $\operatorname{Cr}(\mathrm{vI})$, and $\sim 3.0 \times 10^{5}$ cells per $\mathrm{mL}$ were counted for 15 days of incubation with the maximum removal yields of $14.3 \pm 0.3 \%$ for RB5 and $84.7 \pm 0.4 \%$ for $\mathrm{Cr}(\mathrm{VI})$. The decrease in bacterial count after 7 days is due to the initiation of death phase, which is related with the lack of nutrients in old media and inadequate living conditions for the bacterial cells. It is clear that, with decrease in bacterial count, the removal performances of bacteria/PSUNFW decrease as well for both contaminants, suggesting that the efficiencies of the removal yields are directly correlated with the attached bacteria on PSU-NFW samples. Seven days attachment was found to be adequate for further studies, and RB5 and $\mathrm{Cr}(\mathrm{vI})$ bioremoval experiments were started with bacteria/PSU-NFW samples at this stage.

Electrospun nanofibrous polysulfone webs were employed as a polymeric support matrix for bacterial cells in the current study. It was found that, electrospun PSU-NFW's are effective matrices for immobilizing bacterial cells. The SEM micrographs shows (a) pristine PSU-NFW, (b) bacteria/PSU-NFW after $24 \mathrm{~h}$ incubation, (c) after 7 days of incubation, and (d) after 15 days of incubation from the initiation of the bacterial growth experiments (ESI Fig. S2 $\dagger$ ). Pristine PSU-NFW (Fig. S2a $\dagger$ ) is an effective support system and has an advantage for facilitating the diffusion of nutrients and waste products between the environment and bacteria. In addition, these polymeric webs are non-toxic and biocompatible; which can be rendered for biological applications. After $24 \mathrm{~h}$ of attachment, no biofilm formation are observed but just bacterial cells can be seen. When the incubation time increased to 7 days, bacteria strongly attached onto the nanofibrous web, and the attached bacteria are observed to form a thick biofilm structure by adhering to each other and surrounding the filaments of PSUNFW (Fig. S2c†). However, after 15 days of attachment, the biofilm structures began to lose their characteristic properties, due to lack of nutrition within the medium (Fig. S2d $\dagger$ ). As a result, 7 days of incubation was found to be required for the robust attachment of bacteria onto nanofiber surfaces.

Reactive Black 5 removal by bacteria/PSU-NFW was investigated at an initial concentration of $30 \mathrm{mg} \mathrm{L}^{-1}$ at $\mathrm{pH} 8.0$ for different time intervals. As shown in Fig. 3a, the average RB5 removal efficiency was calculated as $35.8 \pm 0.4 \%$ for the pristine PSU-NFW. After immersion of bacteria/PSU-NFW nanobiocomposite into the liquid media, $99.7 \pm 0.9 \%$ dye was removed after $24 \mathrm{~h}$ incubation. For the $\mathrm{Cr}(\mathrm{vI})$ removal experiments shown in Fig. $3 \mathrm{~b}$, the highest $\mathrm{Cr}(\mathrm{vI})$ removal yields were measured as $98.2 \pm 0.6 \%$ for bacteria/PSU-NFW and $32.6 \pm$ $0.6 \%$ for pristine PSU-NFW. The removal process started after approximately $60 \mathrm{~min}$ and reached to maximum yield after about $24 \mathrm{~h}$. Statistical analyses revealed that there is no statistically significant difference between free bacteria and bacteria/ PSU-NFW removal efficiencies $(P>0.05)$. 


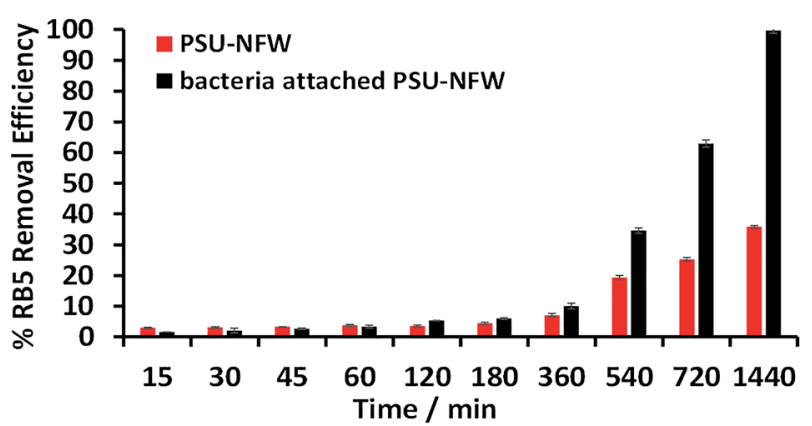

(b)

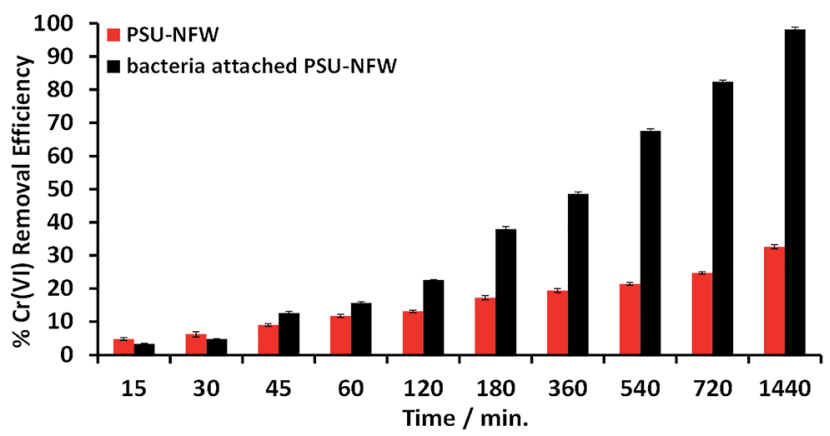

Fig. 3 The single effect of initial (a) RB5 and (b) $\mathrm{Cr}(\mathrm{VI})$ concentrations on the removal efficiency of pristine PSU-NFW and bacteria/PSU-NFW in the media containing $30 \mathrm{mg} \mathrm{L}{ }^{-1}$ of contaminants during the $24 \mathrm{~h}$ incubation period ( $\mathrm{pH}$ : 8.0; temp: $30 \pm 1{ }^{\circ} \mathrm{C}$; stirring rate; $100 \mathrm{rpm}$ ). Error bars represent the means of three independent replicates.

When using pristine PSU-NFW, the removal is mainly due to the uptake by the nanofibrous web, as a physicochemical adsorption process. In contrast, bacteria/PSU-NFW continued its dye/Cr(vi) uptake, by reduction of $\mathrm{Cr}(\mathrm{vI})$ to the lower toxicity form $\mathrm{Cr}(\mathrm{III})$, and adsorption or degradation of the dye by bacterial cells.

Individual removal of $\mathrm{Cr}(\mathrm{vI})^{32}$ or dye $\mathrm{e}^{33}$ have been reported in the literature by various researchers. Whereas, few reports are available on simultaneous removal of dye and $\mathrm{Cr}(\mathrm{vI})$ by using bacterial isolates in pure culture or in a consortium. ${ }^{3}$ Coexistence of dyes and $\mathrm{Cr}(\mathrm{vI})$ in effluents leads to an environmental impact associated with resistance to various effluent treatment procedures. Increase in $\mathrm{Cr}(\mathrm{vI})$ concentration $(15,50$ and $100 \mathrm{mg} \mathrm{L}^{-1}$ ) led to decrease in dye decolorization rate of bacteria/PSU-NFW, $91.8 \pm 0.2 \%, 90.6 \pm 0.7 \%$ and $82.7 \pm 1.1 \%$ (Table S1, ESI $\uparrow$ ) while increase in dye concentration $(15,50$ and $100 \mathrm{mg} \mathrm{L}^{-1}$ ) had a positive impact on $\operatorname{Cr}(\mathrm{vI})$ removal performance (Table S1 $\dagger$ ). It was observed that, an increase in $\mathrm{Cr}(\mathrm{vI})$ concentration reduced the dye decolorization and $\mathrm{Cr}(\mathrm{vr})$ reduction efficiency up to a certain level, whereas an increase in dye concentration enhanced the $\mathrm{Cr}(\mathrm{vI})$ removal yield. As a result, the present isolate showed exceptionally high tolerance and removal performance for both substrates, highlighting the potential of Lysinibacillus sp. NOSK in combating these toxic species.

The growth of Lysinibacillus sp. NOSK isolate in media with or without contaminants is presented in Fig. 4. The cellular growths were observed under its optimal $\mathrm{pH}$ and temperature conditions. To investigate the dye and heavy metal resistance, the isolate was grown in media containing $30 \mathrm{mg} \mathrm{L}^{-1} \mathrm{RB} 5$ and $\mathrm{Cr}(\mathrm{vI})$ individually, $\mathrm{Cr}(\mathrm{vI})\left(30 \mathrm{mg} \mathrm{L}^{-1}\right)$ with varying RB5 concentrations $\left(15,50\right.$ and $\left.100 \mathrm{mg} \mathrm{L}^{-1}\right)$ and RB5 $\left(30 \mathrm{mg} \mathrm{L}^{-1}\right)$ with varying $\mathrm{Cr}(\mathrm{vI})$ concentrations $\left(15,50\right.$ and $\left.100 \mathrm{mg} \mathrm{L}^{-1}\right)$. Growth rates were determined after $24 \mathrm{~h}$. In the medium without RB5 and $\mathrm{Cr}(\mathrm{vI})$ (control), the isolate NOSK produced more biomass than in the medium with RB5 and $\mathrm{Cr}(\mathrm{vI})$. As seen in Fig. 4a, $\mathrm{Cr}(\mathrm{vI})$ affected bacterial cell viability more than RB5 due to toxic property. While the highest optical density (OD) was measured as 1.8 in the medium containing $\mathrm{Cr}(\mathrm{vI})\left(15.4 \mathrm{mg} \mathrm{L}^{-1}\right)$, it reached to 2.82 in the medium containing RB5 $\left(15.2 \mathrm{mg} \mathrm{L}^{-1}\right)$.

\section{Adsorption isotherms and order of reactions}

Adsorption coefficients and their estimated values for each tested isotherm are listed in Table S2 (ESI $\dagger$ ). No linear component was found in $\mathrm{Cr}(\mathrm{vI})$ and RB5 removal by bacteria/PSU-NFW,
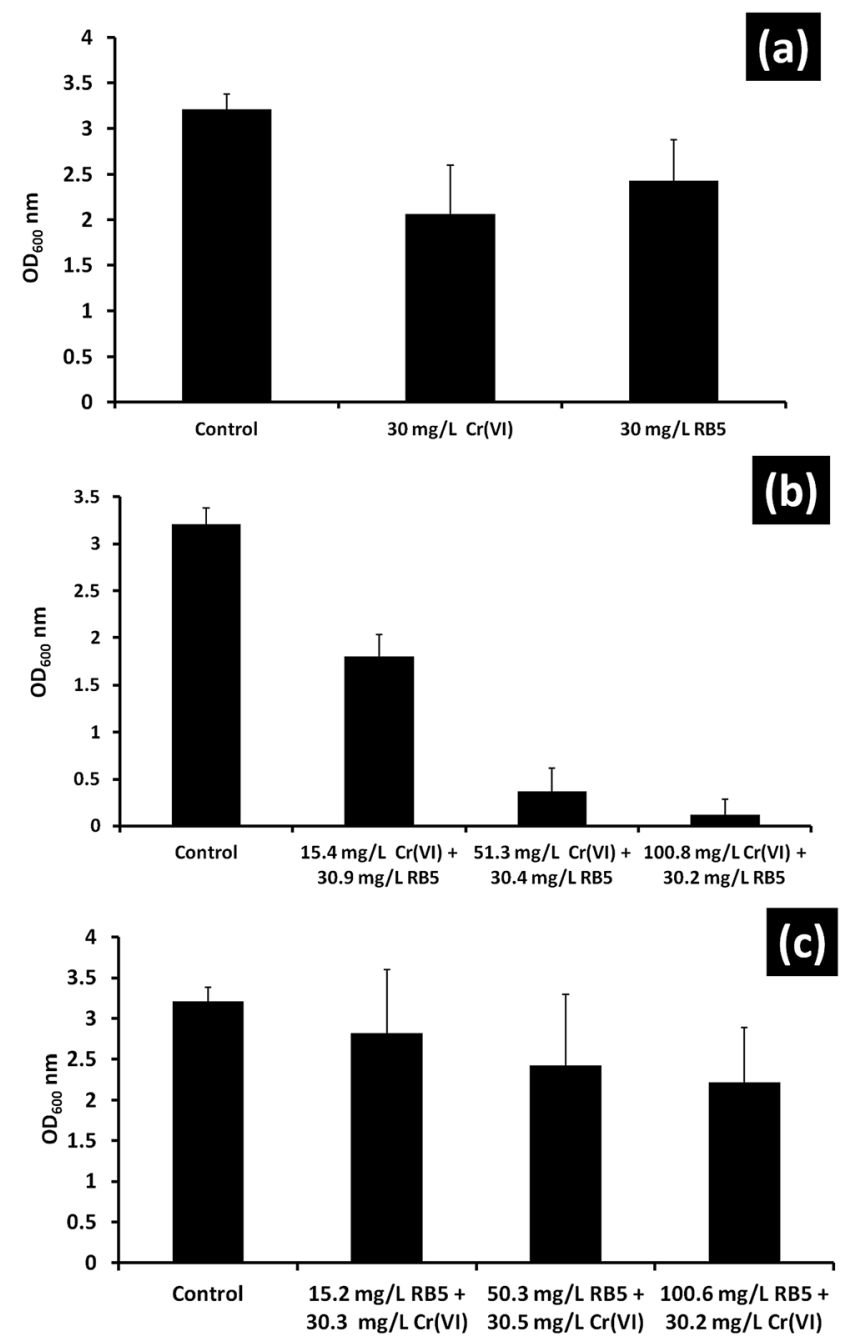

Fig. 4 (a) Single and (b and c) binary effects of RB5 and $\mathrm{Cr}(\mathrm{VI})$ on the biomass growth of Lysinibacillus sp. NOSK (pH: 8.0; temp: $30 \pm 1^{\circ} \mathrm{C}$; stirring rate: $100 \mathrm{rpm}$ ). Error bars represent the means of three independent replicates. 
since linearity assessments for both contaminants are nonlinear in Langmuir and Freundlich models, and $\mathrm{Ry}^{2}$ values for linear isotherms are not sufficiently high. While the Toth generalized isotherm was found to be the best fitting model for RB5 $\left(\mathrm{Ry}^{2}=0.877\right)$, Langmuir and generalized LangmuirFreundlich models were found to be the best fitting models for $\mathrm{Cr}(\mathrm{vI})\left(\mathrm{Ry}^{2}=0.995\right)$. The highest correlations observed in Langmuir and generalized Langmuir-Freundlich isotherms for $\mathrm{Cr}$ (vI) suggests its removal is likely to be monolayeric, whereas the highest correlation observed in Toth isotherm for RB5 suggests its removal is rather heterogenous and multilayeric by bacteria/PSU-NFW. ${ }^{34}$ The maximum removal capacities $\left(Q_{\max }\right)$ of bacteria/PSU-NFW are estimated to be $5.67 \mathrm{mg} \mathrm{g}^{-1}$ for $\mathrm{Cr}(\mathrm{vI})$ under the Langmuir model and $35.17 \mathrm{mg} \mathrm{g}^{-1}$ for RB5 under the Toth model, indicating bacteria/PSU-NFW has a greater removal capacity for RB5 dye.

The $R^{2}$ values of different order plots for $\mathrm{Cr}(\mathrm{vI})$ and RB5 are listed in Table S3 (ESI $\dagger$ ). While the removal of $\mathrm{Cr}(\mathrm{vI})$ shows highest correlation with the zero order model $\left(R^{2}=0.9594\right)$, the removal of RB5 dye shows highest correlation with the first order model $\left(R^{2}=0.9850\right)$. These results are in line with the results from the literature, as enzyme-catalyzed reactions (e.g. RB5 biodegradation) often fall under the zero order, ${ }^{35}$ and $\mathrm{Cr}(\mathrm{vI})$ reduction kinetics have been reported to fit under the first order mechanism. ${ }^{36}$

\section{Reusability}

From the viewpoint of removal studies, it was essential to monitor the reusability of the material and therefore, bacteria/ PSU-NFW was subjected to repetitive exposure of RB5 and Cr(vI) simultaneously. RB5 and $\mathrm{Cr}(\mathrm{vI})$ removal capabilities of bacteria/ PSU-NFW were tested for seven cycles of reuse and shown in Fig. 5. In addition, the fiber morphology of bacteria/PSU-NFW after reusability test is shown in Fig. $S 3, \dagger$ confirmed that the fibrous morphology and bacteria was retained. As can be seen in Fig. 5, the residual concentration of RB5 at the end of the $2^{\text {nd }}$ cycle was $8.01 \mathrm{mg} \mathrm{L}^{-1}$ and the decolorization rate was $76.9 \pm$ $0.8 \%$, yet it decreased to $67 \pm 1.2 \%$ at the end of the $4^{\text {th }}$ cycle. During the subsequent cycles, the rate of dye removal decreased continuously and attained to $28.1 \pm 0.6 \%$ at the end of the $7^{\text {th }}$

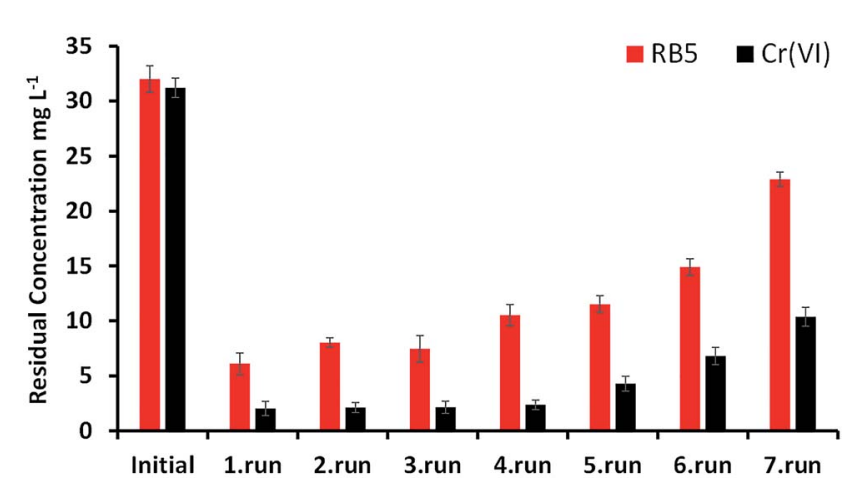

Fig. 5 Reusability test results of the bacteria/PSU-NFW for 7 cycles of RB5 and $\mathrm{Cr}(\mathrm{VI})$ removal at an initial contaminants concentration of 30 $\mathrm{mg} \mathrm{L}^{-1}\left(\mathrm{pH}\right.$ : 8.0; temp: $30 \pm 1^{\circ} \mathrm{C}$; stirring rate: $\left.100 \mathrm{rpm}\right)$. Error bars represent the means of three independent replicates. cycle. The residual concentration of $\mathrm{Cr}(\mathrm{vI})$ at the end of the $2^{\text {nd }}$ cycle was $2.1 \mathrm{mg} \mathrm{L}^{-1}$ and the removal efficiency was $93.2 \pm$ $0.6 \%$, which stayed stable till the end of the $4^{\text {th }}$ cycle $(92.4 \pm$ $0.5 \%$ ), however, the residual $\mathrm{Cr}(\mathrm{vI})$ concentration increased to $10.3 \mathrm{mg} \mathrm{L}^{-1}$ at the end of the $7^{\text {th }}$ cycle, which corresponds a $66.7 \pm 0.8 \%$ removal yield. In each new cycle, due to loss of bacterial attachment, the removal yields decreased. Nevertheless, this result is highly promising, and with a successful optimization, the bacteria/PSU-NFW may be utilized repeatedly for simultaneous remediation of RB5 and $\mathrm{Cr}(\mathrm{vI})$, thus making it an ideal candidate for in situ bioremediation applications.

Simultaneous removal of dye and chromate using fungal and algal species has been reported, but this process is rather slow ${ }^{37}$ and the rate of removal of dye with $\mathrm{Cr}(\mathrm{vI})$ used in these studies were low when compared with the present study. In addition to removal efficiencies data, successfully produced nanofibrous biocomposite has several advantages over the use of free cells in suspension, including lower space and growth medium requirements, ease of handling, and potential reusability of the same matrix over several treatment cycles. Furthermore, attachment of bacterial cells on polymeric network systems makes them more resistant to harsh environmental conditions, such as toxicity or extremes of salinity, temperature and $\mathrm{pH}$.

\section{Biosorption}

Dead biomass is valuable for adsorption of contaminants from the aqueous systems, as the cells are unaffected by toxic wastes, they require no supply of nutrients and can be reused. Hence, biosorption of dyes and metals by dead biomass becomes a promising technique of pollutants removal. ${ }^{38}$ To find out the efficiency of biosorption process, a comparison of bioaccumulation and biosorption is shown in Fig. 6. Maximum RB5 and Cr(vi) biosorptions yield were $92.6 \pm 0.9 \%$ and $67.8 \pm$ $0.1 \%$ respectively. Dye removal efficiency from biosorption was higher than efficiency from bioremoval processes. Bioremoval suffers from significant limitations since more dyestuffs found in the commercial market have been intentionally designed to be resistant to aerobic microbial degradation. Attempts to develop aerobic bacterial strains for dye decolorization often resulted in very specific organisms which showed decolorization capability for individual dyes. ${ }^{39}$ The higher dye uptake may

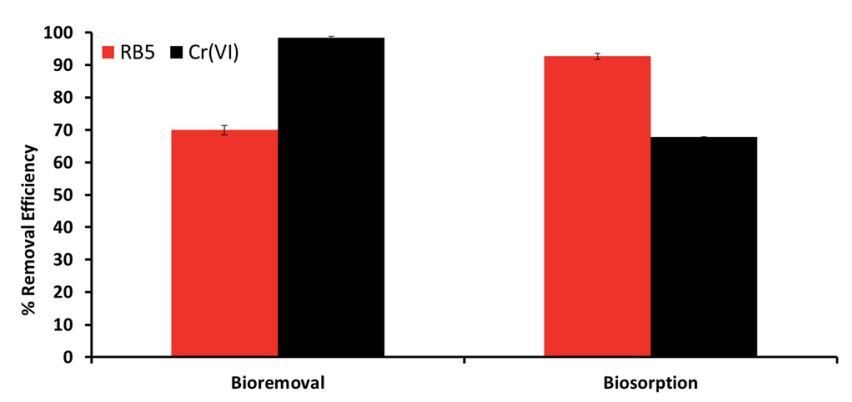

Fig. 6 The comparison of bioremoval and biosorption of RB5 and $\mathrm{Cr}(\mathrm{vl})$ at $30 \mathrm{mg} \mathrm{L}^{-1}$ initial dye and heavy metal concentrations after $24 \mathrm{~h}$ (pH: 8.0; temp: $30 \pm 1{ }^{\circ} \mathrm{C}$; stirring rate: 100 rpm). Error bars represent the means of three independent replicates. 
be explained in terms of electrostatic interactions between the surface of PSU-NFW and reactive dye, or Lysinibacillus sp. NOSK biomass and reactive dye. In addition, dead cells are unaffected by toxic wastes. However biosorption efficiency of $\mathrm{Cr}(\mathrm{vI})$ was decrease with respect to yields from bioaccumulation study. Previous studies on biosorption indicate that $\mathrm{Cr}(\mathrm{vI})$ has a low affinity for biosorption. The bacteria/PSU-NFW nanobiocomposite was capable of removing more than $65 \%$ of both contaminants at an initial concentration of $30 \mathrm{mg} \mathrm{L}^{-1}$.

\section{Conclusions}

An electrospinning technique was used to produce polysulfone nanofibrous web on which bacterium Lysinibacillus sp. NOSK was immobilized. Our results demonstrated that the decolorization capacity of bacteria/PSU-NFW have shown highly efficient removal of RB5 (99.7 $\pm 0.9 \%)$. Moreover, the highest $\mathrm{Cr}(\mathrm{vI})$ removal efficiencies measured were $98.2 \pm 0.6 \%$. Our novel bacteria/PSU-NFW material has certain advantages in terms of application. Firstly, bacteria/PSU-NFW can be reusable. Secondly, bacteria/PSU-NFW requires lower volume of medium for storage. Therefore, bacteria/PSU-NFW nanobiocomposite can be effectively utilized for the treatment of wastewater containing both RB5 and $\mathrm{Cr}(\mathrm{vI})$, with cost-effective and reusable properties.

\section{Acknowledgements}

The Scientific and Technological Research Council of Turkey (TUBITAK, project \#114Y264) is acknowledged for funding the research. Dr Uyar also acknowledges The Turkish Academy of Sciences - Outstanding Young Scientists Award Program (TUBAGEBIP) for partial funding of the research. A. Celebioglu acknowledges TUBITAK (project \#113Y348) for a postdoctoral fellowship.

\section{Notes and references}

1 S. M. King, H. P. Jarvie, M. J. Bowes, E. Gozzard, A. J. Lawlor and M. J. Lawrence, Environ. Sci.: Nano, 2015, 2, 177.

2 H. Su, Y. Zhang, C. Zhang, X. Zhou and J. Li, Bioresour. Technol., 2011, 102, 9884.

3 S. Ertugrul, N. O. San and G. Dönmez, Ecol. Eng., 2009, 35, 128.

4 P. Kaur, V. K. Sangal and J. P. Kushwaha, RSC Adv., 2015, 5, 34663.

5 A. R. Binupriya, M. Sathishkumar, C. S. Ku and S. Yun, Colloids Surf., B, 2010, 76, 179.

6 L. Brinza, C. A. Nygard, M. J. Dring, M. Gavrilescu and L. G. Benning, Bioresour. Technol., 2009, 100, 1727.

7 Y. Long, Q. Li, J. Ni, F. Xu and H. Xu, RSC Adv., 2015, 5, 29145. 8 H. Li, Z. Li, T. Liu, X. Xiao, Z. Peng and L. Deng, Bioresour. Technol., 2008, 99, 6271.

9 R. Wani, K. M. Kodam, K. R. Gawai and P. K. Dhakephalkar, Appl. Microbiol. Biotechnol., 2007, 75, 627.

$10 \mathrm{Y}$. Tanaka, Fundamental properties of ion exchange membranes, Elsevier, 2nd edn, 2015.
11 H. Huang, C. Xu and W. Zhang, Bioresour. Technol., 2011, 102, 2523.

12 H. D. Raval, P. S. Rana and S. Maiti, RSC Adv., 2015, 5, 6687.

13 H. Thatoi, S. Das, J. Mishra, B. Prasad Rath and N. Das, J. Environ. Manage., 2014, 146, 383.

14 X. Zhao, J. Ma, H. Ma, D. Gao, C. Zhu and X. Luo, RSC Adv., 2014, 4, 56831.

15 C. J. Ogugbue, T. Sawidis and N. A. Oranusi, Ecol. Eng., 2011, 37, 2056.

16 J. H. Wendorff, S. Agarwal and A. Greiner, Electrospinning: Materials, Processing, and Applications, Wiley-VCH, 2012.

17 A. Celebioglu, S. Demirci and T. Uyar, Appl. Surf. Sci., 2014, 305, 581.

18 S. Demirci, A. Celebioglu and T. Uyar, Carbohydr. Polym., 2014, 113, 200.

19 A. Greiner and J. H. Wendorff, Angew. Chem., Int. Ed., 2007, 46, 5670 .

20 F. Kayaci, Z. Aytac and T. Uyar, J. Hazard. Mater., 2013, 261, 286.

21 J. Hoon Doh, J. Hyun Kim, H. Jin Kim, R. Faryad Ali, K. Shin and Y. Joon Hong, Chem. Eng. J., 2015, 277, 352.

22 S. Ramakrishna, K. Fujihara, W. E. Teo, T. Yong, Z. Ma and R. Ramaseshan, Mater. Today, 2006, 9(3), 40.

23 E. Eroglu, V. M. Bradshaw, X. Chen, S. M. Smith, C. L. Raston and K. Y. Iyer, Green Chem., 2012, 14, 2682.

24 M. Greque de Morais, C. Stillings, R. Dersch, M. Rudisile, P. Pranke, J. A. Vieira Costa and J. Wendorff, Bioresour. Technol., 2010, 101, 2872.

25 N. O. San Keskin, A. Celebioglu, T. Uyar and T. Tekinay, Ind. Eng. Chem. Res., 2015, 54(21), 5802.

26 O. F. Sarioglu, O. Yasa, A. Celebioglu, T. Uyar and T. Tekinay, Green Chem., 2013, 15, 2566.

27 N. O. San Keskin, A. Celebioglu, T. Uyar and T. Tekinay, RSC Adv., 2014, 4, 32249.

28 E. Keskin and H. Atar, Mol. Ecol. Resour., 2013, 13, 788.

29 H. Wagner, T. Siebert, D. J. Ellerby, R. L. Marsh and R. Blickhan, Biomech. Model. Mechanobiol., 2005, 4, 10.

30 http://www.ncbi.nlm.nih.gov/nuccore/699017893.

31 J. Lin, X. Zhang, Z. Li and L. Lei, Bioresour. Technol., 2010, 101,34 .

32 E. M. Contreras, A. M. Ferro Orozco and N. E. Zaritzky, Water Res., 2011, 45, 3034.

33 O. Anjaneya, S. Y. Soucheb, M. Santoshkumara and T. B. Karegoudara, J. Hazard. Mater., 2011, 190, 351.

34 Z. Ergul-Ulger, A. D. Ozkan, E. Tunca, S. Atasagun and T. Tekinay, Sep. Sci. Technol., 2014, 49, 907.

35 I. Tinoco, K. Sauer and J. C. Wang, Physical Chemistry Principles and Applications in Biological Sciences, Prentice Hall, 1996.

36 V. Lugo-Lugo, C. Barrera-Díaz, B. Bilyeub, P. BalderasHernández, F. Ureña-Nuñez and V. Sánchez-Mendieta, J. Hazard. Mater., 2010, 176, 418.

37 Y. M. Kolekar, P. D. Konde, V. L. Markad, S. V. Kulkarni, A. U. Chaudhari and K. M. Kodam, Appl. Microbiol. Biotechnol., 2012, 97, 881.

38 N. O. San and G. Dönmez, Water Sci. Technol., 2012, 65(3), 471. 39 Z. Aksu and G. Dönmez, Chemosphere, 2003, 50, 1075. 